RECYT

Year 23 / No 36 / 2021 / 46-52

\title{
Impact of the packaging of plain soymilk on the intention to purchase of the consumer
}

\author{
Impacto del envase de la leche de soja natural en la intención de compra del \\ consumidor
}

\section{Impacto da embalagem de bebida de soja sabor original na intenção de compra de consumidores}

\author{
Pedro Augusto dos Santos Baleroni ${ }^{1}$, Marta de Toledo Benassi², \\ Marines Paula Corso ${ }^{3}$, Marcela Moreira Terhaag1, * \\ 1- Instituto Federal do Paraná (IFPR), Campus Umuarama, Brazil. \\ 2- Universidade Estadual de Londrina (UEL), Departamento de Ciência e Tecnologia de Alimentos, Brazil. \\ 3- Universidade Tecnológica Federal do Paraná (UTFPR), Campus Medianeira, Núcleo de Ciência de Alimentos, Brazil. \\ * E-mail: marcela.terhaag@ifpr.edu.br
}

\section{Abstract}

Received: 14/09/2020; Approved: 18/06/2021

\begin{abstract}
The objective of this work was to evaluate the intention to purchase plain soymilk by correlating it with packaging characteristics through the conjoint analysis. Survey of attributes occurred by focus group (41 participants) and five samples of Brazilian original soymilk. Main attributes that interfered in the purchase decision: brand, presence of nutritional appeal, type of illustration of glass containing beverage and background color. Attributes were combined to generate eight packaging proposals, evaluated by 86 participants. SAS was used for data analysis, 85 of which were consistent. Participants were grouped by similarities/dissimilarities in three groups: G1 (48 participants), G2 (31) and G3 (6). G1 preferred packaging containing nutritional appeal and light background, being influenced by the brand. G2 opted for packaging containing nutritional appeal, lesser-known brand and filled glass. G3 preferred the presence of nutritional appeal, lesser known brand, full glass and dark background. Presence of nutritional appeal is the factor that most impacts the purchase decision, but the brand, type of glass illustration and background color are relevant. Packaging with the presence of nutritional appeal, glass with full filling and clear background is more likely to be of interest to consumers.
\end{abstract}

Keywords: Focus group; conjoint analysis; behavior; preference.

\section{Resumen}

El objetivo de este trabajo fue evaluar la intención de compra de la leche de soja natural correlacionándola con las características del envase a través del análisis conjunto. El estudio de los atributos se realizó mediante un grupo focal (41 participantes) y cinco muestras de leche de soja original brasileña. Principales atributos que interfirieron en la decisión de compra: marca, presencia de atractivo nutricional, tipo de ilustración del vaso que contiene la bebida y color de fondo. Los atributos se combinaron para generar ocho propuestas de envase, evaluadas por 86 participantes. Se utilizó SAS para el análisis de los datos, 85 de los cuales fueron consistentes. Los participantes se agruparon por similitudes/disimilitudes en tres grupos: G1 (48 participantes), G2 (31) y G3 (6). El G1 prefirió un envase que contuviera un atractivo nutricional y un fondo claro, estando influenciado por la marca. El G2 optó por un envase con atractivo nutricional, una marca menos conocida y un vaso relleno. El G3 prefirió la presencia del atractivo nutricional, la marca menos conocida, el vaso lleno y el fondo oscuro. La presencia del atractivo nutricional es el factor que más influye en la decisión de compra, pero la marca, el tipo de ilustración del vidrio y el color del fondo son relevantes. Los envases con presencia de atractivo nutricional, vidrio con relleno completo y fondo claro tienen más probabilidades de interesar a los consumidores.

Palabras clave: Grupo de discusión; Análisis conjunto; Comportamiento; Preferencia. 


\section{Resumo}

Objetivou-se neste trabalho avaliar a intenção de compra de bebidas de soja sabor original correlacionando-a com características da embalagem por meio da análise conjunta de fatores. Levantamento dos atributos ocorreu por grupo de foco (41 participantes) e cinco amostras de bebida de soja brasileiras. Principais atributos que interferiam na decisão de compra: marca, presença de apelo nutricional, tipo da ilustração de copo contendo bebida e cor do fundo. Atributos foram combinados gerando oito propostas de embalagens, avaliadas por 86 participantes. Usouse o SAS para análise dos dados, sendo 85 destes consistentes. Agruparam-se participantes por similaridades/ dissimilaridades em três grupos: G1 (48 participantes), G2 (31) e G3 (6). G1 preferiu embalagem contendo apelo nutricional e fundo claro, sendo influenciado pela marca. Já o G2 optou por embalagem contendo apelo nutricional, marca menos conhecida e copo preenchido. G3 preferiu presença de apelo nutricional, marca menos conhecida, copo cheio e fundo escuro. Presença do apelo nutricional é o fator que mais impacta na decisão de compra, mas a marca, tipo de ilustração de copo e cor do fundo são relevantes. Embalagem com presença do apelo nutricional, copo com preenchimento total e fundo claro tem maior probabilidade de interesse de compra pelos consumidores.

Palavras-chave: grupo de foco; análise conjunta de fatores; comportamento; preferência.

\section{Introduction}

Soy beverages can be obtained from whole soybeans, by aqueous extraction or by suspension of isolated soy protein in water, and they are usually sold in carton packs after being submitted to the UHT (Ultra High Temperature) technique. Due to the increasing number of product launches in this segment, there is a difference between the information printed on the packages. Amid the COVID-19 crisis, the global soymilk market, estimated at $\$ 11.6$ billion in the year 2020, is expected to reach a revised size of $\$ 16.5$ billion by 2027 (Research and Markets, 2021b). Of the soymilk formulation options, the best-selling is called plain or original and accounted for over $52.7 \%$ of the market share in 2016 (Research and Markets, 2021a).

As packaging is key in product purchase selection and decision (Della Lucia et al., 2007), the information on the package and the consumer's expectation in relation to the product (Deliza et al., 2000; Dantas et al., 2005) can be assessed subjectively using qualitative tests such as the focus group technique (Dutcosky, 2013).

The focus group is a method of exploratory nature, with the goal of providing ideas about preferences, incentives and barriers to certain behaviors (van Kleef, van Trijp \& Luning, 2005a). It allows participants to explain motivations and reasons for their attitudes, preferences, and perceptions in a roundtable session conducted by an impartial moderator (Della Lucia; Minin; Carneiro, 2010; Dutcosky, 2013). The factors and levels determined in the focus group can be used in other research methods such as the conjoint factor analysis.

Conjoint factor analysis (CFA) is commonly used to get information on the effect of different attributes on the consumer preference and/or purchase intent. It uses the scores assigned for the different product and service versions and the knowledge of factors/levels that constitute each one of these versions, to determine the contribution or the value of factorial levels (Carneiro et al., 2003).
Therefore, the objective of the present research was $s$ to identify the impact of the attributes of soy beverage packages original flavor on product purchase intent, and to propose a package that can influence this purchase positively.

\section{Materials and Methods}

Participants were informed about the procedures, as registered in the National System of Ethics in Research (Certificate of Presentation for Ethical Appreciation $\mathrm{n}^{\circ}$ 0142.0.268.000-09).

\section{Definition of attributes and their levels}

To define the attributes and levels applied during the conjoint analysis (CA), focus group sessions were conducted, as suggested by Della Lucia, Minim and Carneiro (2010). During the interview, five packages of Brazilian plain soymilk, from different brands, were presented sequentially to the participants. The packages were Tetra Pak Brik Squareline ${ }^{\circledR}$ type carton (square bottom), with a plastic lid with an open-and-close system and aluminum seal (Tetra Pak ${ }^{\circledR}$ pull tab system with recap). In the supplementary material (Annex 1- Table 1) there is a description of the five packages used in the research. The focus group consisted of 7 sessions of approximately 90 minutes, in which 41 individuals participated, selected and characterized from questionnaires collecting personal data, frequency of soy drink consumption and reading of food product labels, in addition to habits of purchase. The groups were divided according to the characteristics of the participants, so that the sessions represented their opinion, and information of interest to the product was obtained. Participants were encouraged by the moderator to express opinions. In order to standardize the conduct of the sessions, we used some questions, made without order specificity, according to the context and group dynamics: a) what did you think of this package?; b) what 
attracts your attention about this packaging and label?; c) Do nutritional information and ingredients influence your purchase intention?; d) Do you like to see the expression " $0 \%$ cholesterol, $0 \%$ lactose" or "lactose-free, cholesterolfree" on packaging?; e) What do you mean by original flavor?; f) How to inform on the label that this product is fortified/enriched?; g) Which nutrient do you believe is most important to be highlighted on the label of this product?; h) Would you like to see any other information on the label of this product?; i) Would you like to see any changes in terms of packaging design (shape, material, cover)?; j) Would you like to see any changes in terms of label design (colors, figure, font)?

At the end of each session, all packages were evaluated together and each participant made their own general evaluation, justifying their criteria. In each session, the data obtained through the answered questionnaires and the opinions of the participants were recorded, analyzed and discussed considering the words used by consumers, the context of the question and the specificity of the answers and, when possible, represented by the use of percentage values.

\section{Conjoint analysis: experimental design, packaging development and evaluation of results}

From the data collected through the focus group, 8 packaging proposals for plain soymilk were elaborated, corresponding to a fractional factorial design with four factors and two levels $\left(2^{4-1}\right)$. The following factors were used: a) brand, b) type of cup illustration: cup with product projection coming out of the cup, in the form of drops and splashes (denoted in this work as splash) or, cup filled with product, c) presence/absence of nutritional claims (more nutritious, with calcium and vitamins) and, d) background color (light/dark), as shown in Table 1. The images were assembled using the PowerPoint $\AA$ and Paint ${ }^{\circledR}$ programs, defining as a packaging proposal only the image of the front panel.

Table 1: Experimental design of plain soymilk.

\begin{tabular}{|c|c|c|c|c|}
\hline $\begin{array}{c}\text { Proposed } \\
\text { packaging }\end{array}$ & Brand & $\begin{array}{c}\text { Glass } \\
\text { ilustration }\end{array}$ & $\begin{array}{c}\text { Nutritional } \\
\text { information }\end{array}$ & $\begin{array}{c}\text { Background } \\
\text { Color }\end{array}$ \\
\hline 1 & Best known & With splash & Presence & Light \\
\hline 2 & Less known & With splash & Absence & Light \\
\hline 3 & Best known & Filled & Absence & Light \\
\hline 4 & Best known & Filled & Presence & Dark \\
\hline 5 & Best known & With splash & Absence & Dark \\
\hline 6 & Less known & Filled & Presence & Light \\
\hline 7 & Less known & Filled & Absence & Dark \\
\hline 8 & Less known & With splash & Presence & Dark \\
\hline
\end{tabular}

For the ACF, 86 participants were used, in sessions with a variable number of participants, according to their availability. The sessions were conducted in a classroom containing a computer connected to multimedia projection equipment, at the Federal Institute of Paraná (Umuarama/ Brazil). At each session, the order of presentation of the images was randomized and the images coded by 3 digits randomized.

Participants were asked to behave as if they were in a supermarket and needed to buy plain soymilk, and that, for each image presented, they wrote down the sample number and registered the respective purchase intention. Initially, the 8 proposed packages were presented on the same slide for 15 seconds, so that participants could have an overview of the products. Subsequently, packages coded with 3-digit numbers were presented sequentially for 30 seconds, using a 10-second interval of white screen between each image. The order of presentation was randomized in each session. The sample number was noted for each packaging image, and the purchase intention of each participant was evaluated on a scale. To assess purchase intention, a 7-point structure scale was used, anchored at the lower end with the expression "definitely not buy" and at the upper end "I would definitely buy".

The results were tabulated as grades ( 1 to 7 ) for each package evaluated, in a table of double entry of consumers versus packages and analyzed using the SAS program (SAS INSTITUTE INC, 1996) as suggested by Carneiro et al. (2005). For the assessment of purchase intention, preference coefficients were calculated for all consumers, in an individual analysis, according to Corso and Benassi (2015), through an additive model, where the general assessment of preference (purchase intention ) was formed by the sum of the contributions at each of the levels of each factor (packaging attributes).

Subsequently, consumers were grouped into groups through cluster analysis, using the linkage average method and the Euclidean distance as a measure of similarity. Based on the estimated preference coefficients for the groups, the relative importance of the variables on the purchase intention of consumers in each group was evaluated. Clusters formed by a very small number of consumers, that is, that did not represent groups, were repositioned in other larger clusters that presented similar preference behavior. The Fischer and Tukey tests were applied to the results in order to verify if there was a significant difference between the coefficients for each attribute within the group $(\mathrm{p}<0.05)$.

\section{Results and discussion}

\section{Focus group}

Consumers were predominantly women (79\%); the participants had between 40 to 69 years of age (59\%), with high educational attainment $(22 \%$ with graduate degrees and $24 \%$ with post-graduate degrees) and with incomes between one and ten times the Brazilian minimum wage (91\%). The majority of the participants (42\%) 
was responsible for purchasing food for their homes. Participants (90\%) bought soy beverages with juice, plain or light plain, and the average consumption of soy beverages by the team was 1.34 liter/ month.

Most participants $(61 \%)$ always or often read the labels of the products they consumed and reported in the questionnaire that the attributes price, brand, shelf life, and nutritional information were observed on the product label. According to Wardle, Parmenter, and Waller. (2000), Cowburn and Stockley (2005), Ares et al. (2008b), Karamravan, Koohi and Abbaszadeh (2014), nutritional knowledge can have an influence on eating behavior, influencing consumer choices

Studies show a relation between soybean-based food consumption and nutritional knowledge level (Wansink; Westgren; Cheney 2005). In relation to the characteristics observed at the moment of purchase, most consumers mentioned: a) price (more than 70\%), followed by: b) shelf-life $(58 \%), \mathrm{c})$ brand and d) presence of nutritional claims (47\% and 41\%, respectively).

According to participants, product brand was related to both previous positive purchasing experiences and preferences for the background color of the main panel. Similarly, Ares et al. (2011) verified that, for Spanish consumers, the commercial brand of a yogurt was a relevant factor.

Another factor mentioned was the preference, of some participants. for packages with a lighter background or, of other ones, for packages with a darker background. Another characteristic reported as attractive was type of illustration showing a glass filled with the product printed on the package's main panel. Some participants mentioned as positive the presence of a glass filled with the product and others showed preference for the illustration showing a glass being filled with the beverage, with product splashes. According to Ares et al. (2008a), food companies need to differentiate their products to make them more attractive to consumers. This way, different illustrations and colors used on the packages may promote interest in the acquisition of the product by the consumer. A summary of the main participants' comments is presented as supplementary material (Annex 2- Table 2).

There were several reports on the preference for products with nutritional claims since most participants purchased soy beverages for health reasons, which for them "are much healthier than milk drinks".

Since most participants mentioned the attribute "lower price" and the fact that the product's expiration date is a legal requirement, we decided to vary following factors into two levels: (1) brand, (2) illustration, (3) presence of nutritional claims and, (4) package's background color.

\section{Factorial conjoint analysis}

The group of participants were balanced in gender $(51 \%$ women); they were young ( $85 \%$ between 15 and 35 years of age) and were responsible for purchasing food for their homes (98\%) and frequently read product labels (63\%). They had a high level of education ( $43 \%$ with a college degree), and income of up to five times the Brazilian minimum wage $(67 \%)$.

After the visual assessment of the images by the participants and data analysis, data from one participant who had assigned the same grade to all packages were removed, as suggested by Carneiro et al. (2003). The remained data were assessed individually and showed $\mathrm{p}>$ 0.15 e $\mathrm{R}^{2}>0.66$.

Participants were grouped by similarities and dissimilarities into three (3) main groups with 48, 31 and 6 participants, respectively. Table 2 presents the results of the aggregated analyses for each group.

Table 2: Result of aggregated analyzes for each group.

\begin{tabular}{|c|c|c|c|}
\hline & $\begin{array}{c}\text { Group } 1 \\
(n=48)\end{array}$ & $\begin{array}{c}\text { Group } 2 \\
(n=31)\end{array}$ & $\begin{array}{c}\text { Group } 3 \\
(n=6)\end{array}$ \\
\hline$\%$ of total participants & 56.5 & 36.5 & 7.0 \\
\hline p (group) & $<0.0001$ & $<0.0001$ & $<0.0001$ \\
\hline \multirow[t]{2}{*}{$\mathrm{R}^{2}$ (group) } & 0.14 & 0.70 & 0.60 \\
\hline & \multicolumn{3}{|c|}{ Preference coefficients* } \\
\hline \multicolumn{4}{|l|}{ Claims } \\
\hline 1. Absence & $-0.61^{b}$ & $-1.72^{b}$ & $-1.12^{b}$ \\
\hline 2. Presence & $0.61^{\mathrm{a}}$ & $1.72^{\mathrm{a}}$ & $1.12^{\mathrm{a}}$ \\
\hline Relative importance (\%) & 50.86 & 74.31 & 32.14 \\
\hline \multicolumn{4}{|l|}{ Brand } \\
\hline 1. Best known & $-0.13^{b}$ & $-0.40^{\mathrm{b}}$ & $-0.37^{b}$ \\
\hline 2. Less known & $0.13^{\mathrm{a}}$ & $0.40^{\mathrm{a}}$ & $0.37^{a}$ \\
\hline Relative importance (\%) & 10.35 & 17.36 & 10.71 \\
\hline \multicolumn{4}{|l|}{ Glass ilustration } \\
\hline 1. With splash & $0.06^{\mathrm{a}}$ & $-0.16^{b}$ & $-1.50^{\mathrm{b}}$ \\
\hline 2. Filled-up & $-0.06^{a}$ & $0.16^{\mathrm{a}}$ & $1.50^{\mathrm{a}}$ \\
\hline Relative importance (\%) & 5.17 & 7.29 & 42.86 \\
\hline \multicolumn{4}{|l|}{ Background Color } \\
\hline 1. Light & $0.41^{\mathrm{a}}$ & $0.02^{\mathrm{a}}$ & $-0.50^{\mathrm{b}}$ \\
\hline 2. Dark & $-0.41^{b}$ & $-0.02^{\mathrm{a}}$ & $0.50^{\mathrm{a}}$ \\
\hline Relative importance (\%) & 33.62 & 1.04 & 14.29 \\
\hline
\end{tabular}

* Coefficients with a positive sign indicate a positive impact on the consumer's purchase intention. Different letters in the same column for the same attribute and group denote a significant difference using Tukey and Fisher tests $(p<0,05)$.

One aspect previously raised during the focus group sessions and cited again during the CFA was that product price was a relevant aspect and that purchase decision was based on low product values.

In general, all groups (Table 2) pointed out as positive the presence of nutritional claims on the package, differentiated by certain visual characteristics, which would possibly influence purchase decision. Crilly Moultrie and Clarkson (2004) show that there is a major influence of the package on the purchase decision process, since it attracts consumers' attention to products, conveying messages about the product in a graphic form (Moskowitz 
et al., 2009) serving as product recognition, as well as information on lifestyle (Van Dam; Van Trijp, 1994).

For Group 1, representing 56.5\% of the assessors, purchasing intent was affected significantly by the presence of a nutritional claim, the brand and the main panel with a light background. As for Group 2, the characteristics that made greater impact on purchasing intent was the presence of a claim $(74.31 \%)$, plus the brand and the filled-up glass illustration (17.36\% and 7.29\%, respectively). Purchase intent in Group 3, representing 7\% of the participants, was affected by all the attributes studied. In this group, however, type of glass was the most important factor and the filled-up glass illustration made a positive impact on purchase intent, as well as the less known brand.

Other aspects that may be taken into account in the analysis are that participants were usual consumers of soy beverages and that the images generated contained visual elements similar to those found in commercial samples, i.e., these elements were already known, consciously or unconsciously, by the participants, raising expectations regarding the products. In a review on the subject, Deliza and MacFie (1996) comment on the expectations raised by the consumers' previous experiences with the product, information on the label, packaging characteristics and the product itself, mainly its appearance. Therefore, it is highly relevant for the first experience with the product to be positive, meeting all the sensorial and hedonic expectations of the consumer.

Most participants considered the presence of nutritional appeals an important decision-making factor in purchasing soybean-based beverages. Thus, although consumers had an interest in consuming functional food products, the development of persuasive health allegations and adequate marketing strategies is very difficult, as pointed out by van Kleef, van Trijp e Luning (2005b). Therefore, the adequacy of packaging and product to meet consumers' expectations may enhance the success of a given product (Chung et al., 2011). According to Ares et al. (2008a) the inclusion of information on the source of ingredients may raise negative expectations in relation to the flavor of soy beverages, and special attention should be given to the most adequate way to include this information in the label. Thus, when consuming food, not only health factors will be perceived, but, as in any conventional food, factors such as sensorial quality, price and convenience will also influence consumers' attitudes, which are segmented according to their attitudes and preferences. The identification of these segments may allow us to target different types of products to each segment (Ares et al., 2010b).

\section{Conclusion}

By associating qualitative information from the focus group and the joint factor analysis, some parameters stood out as being important for the purchase decision process of original flavored soy beverages, although the weight of these attributes is different depending on the consumer.

The presence of some nutritional claim is considered an important aspect for the originally flavored soybeanbased beverage acquisition process. The "glass containing the bottled beverage" illustration, the tone of the package background and the brand are factors that segment consumers during the purchase of original flavored soybean beverages.

In general, the package with the presence of a nutritional claim, a filled-up glass and a light background has a higher probability of increasing purchase interest by consumers.

Based on this information, it is possible to conclude that the objective of different package layouts for original flavored soybean-based beverages is to meet the needs of several consumer segments thus justifying the presence of several information and layout options on the product's packages.

\section{References}

1. Ares, G.; Gimenez, A.; Gambaro, A. Does information about the source of functional ingredients influence consumer perception of functional milk desserts? Journal of the Science of Food and Agriculture, v. 88, p. 2061-2068, 2008a.

2. Ares, G.; Gimenez, A.; Gambaro, A. Influence of nutritional knowledge on perceived healthiness and willingness to try functional foods. Appetite, v. 51, p. 663-668, 2008b.

3. Ares, G.; Piqueras-Fiszman, B.; Varela, P.; Marco, R. M.; López, A. M.; Fiszman, S. Food labels: Do consumers perceive what semiotics want to convey? Food Quality and Preference, v. 22, p. 689-698, 2011.

4. Carneiro, J. D. S; Silva, C. H. O.; Minim, V. P. R. Regazzi, A. J.; Deliza, R.; Suda, I. R. Princípios básicos da conjoint analysis em estudos do consumidor. Boletim da Sociedade Brasileira de Ciencia e Tecnologia de Alimentos, n. 37 (supl), p. 107-114, 2003.

5. Carneiro, J. D. S.; Minim, V. P. R.; Deliza, R.; Silva, C. H. O.; Carneiro, J. C. S.; Leão, F. P. Labelling effects on consumer intention to purchase for soybean oil. Food Quality and Preference, v. 16, n. 3, p. 275-282, 2005.

6. Chung, H. S.; Hong, H. D.; Kim, K.; Cho, C. W.; Moskowitz, H. R.; Lee, $\mathbf{S}$. Y. Consumer attitudes and expectations of ginseng food products assessed by focus groups and conjoint analysis. Journal of Sensory Studies, n. 26, p. 346-357, 2011.

7. Cowburn, G.; Stockley, L. Consumer understanding and use of nutrition labelling: a systematic review. Public Health Nutrition, v. 8, n. 1, p. 21-28, 2005.

8. CORSO, M.; BENASSI, M. T. Packaging attributes of antioxidant-rich instant coffee and their influence on the purchase intent. Beverages, v. 1, n. 4, p. 273-291, 2015. 
9. Crilly, N.; Moultrie, J.; Clarkson, P. J. Seeing things: Consumer response to the visual domain in product design. Design Studies, v. 25, p. 547-577, 2004.

10. Della Lucia, S. M.; Minim, V. P. R.; Carneiro, J. D. S. Análise sensorial de alimentos. In: MINIM, V.P.R. Análise sensorial: estudos com consumidores. Viçosa: UFV, 2010. pp. 15-19.

11. Della Lucia, S. M.; Minim. V. P. R.; Silva, C. H. O.; Minim, L. A. Fatores da embalagem de café orgânico torrado e moído na intenção de compra do consumidor. Ciência e Tecnologia de Alimentos, v. 27, p. 485-491, 2007.

12. Deliza, R.; Macfie, $\mathbf{H}$. The generation of sensory expectation by external cues and its effect on sensory perception and hedonic ratings: A review. Journal of Sensory Studies, v. 11, n. 2, p. 103 - 128, 1996.

13. Deliza, R.; Macfie, H.; Hedderley, D.; Frewer, L. Non conventional technologies and impact on consumer behavior. Trends in Food Science and Technology, v. 11, n. 4, p. 188-193, 2000.

14. Dutcosky, S. D. Análise sensorial de alimentos. 4. ed. Curitiba: Champagnat, 2013. 531 p.

15. Karamravan, נ.; Koohi, к. ABBASZADEH, M. Nutrition knowledge and eating behavior. Advances in Environmental Biology, n. 8, v. 25, p. 862-867, 2014.

16. Moskowitz, H.; Silcher, M.; Beckley, J.; Minkus-Mckenna, D.; Mascuch, т. Sensory benefits, emotions and usage patterns for olives: using Internet-based conjoint analysis and segmentation to understand patterns of response. Food Quality and Preference, n. 16, p. 369-382, 2005.
17. Research And Markets. "Dairy alternatives market size, share \& trend analysis report by product (soy milk, almond milk, rice milk), by formulation (plain, flavored), by application, and segment forecasts, 2013 - 2024". Disponível em: https:/www.researchandmarkets.com/ reports/4538777/dairy-alternatives-market-size-shareand-trend\#src-pos-4. Acesso em: 12 de mai. de 2021.

18. Research And Markets. "Soy Milk - Global market trajectory \& analytics". Disponível em: https://www.researchandmarkets.com/reports/5302241/soy-milk-globalmarket-trajectory-and-analytics\#tag-pos-1. Acesso em 11 de mai. de 2021.

19. Sas Institute Inc. SAS Users' Guide: statistics, version 6.12. Cary: SAS Institute, 1996.

20. Van Dam, Y. K.; Van Trijp, H. C. M. Consumer perceptions of, and preferences for, beverage containers. Food Quality and Preference, v. 5, p. 253-261, 1994.

21. Van Kleef, E.; Van Trijp, H. C. M.; Luning, P. Consumer research in the early stages of new product development: A critical review of methods and techniques. Food Quality and Preference, v. 16, p. 181-201, 2005a.

22. Van Kleef, E.; Van Trijp, H. C. M.; Luning, P. Functional foods: health claim-food product compatibility and the impact of health claim framing on consumer evaluation. Appetite, v. 44, p. 299-308, 2005b.

23. Wansink, B.; Westgren, R. E.; Cheney, M. M. Hierarchy of nutritional knowledge that relates to the consumption of a functional food. Nutrition, v. 21, p. 264-268, 2005.

24. Wardle, J.; Parmenter, K.; Waller, J. Nutrition knowledge and food intake. Appetite, v. 34, p. 269-275, 2000. 


\section{Supplementary material}

Annex 1. Table 1: Description of plain soymilk used to identify attributes in the focus group

\begin{tabular}{|c|c|}
\hline Product & Packaging description \\
\hline A & $\begin{array}{l}\text { Main panel in light color, predominantly white, with an illustration of a green field with dawn in the background. Predominant figure of a glass containing a light } \\
\text { beige liquid with a splash, brand name in green color and other information on the main panel with letters in green and blue-green. Product flavor name printed } \\
\text { within a sky blue band with white lettering. Claims packaging: "source of protein and calcium fortified with vitamins", "lactose and 0\% cholesterol because it is } \\
\text { a food with soy", "no preservatives", "My Choice". }\end{array}$ \\
\hline B & $\begin{array}{l}\text { Main panel containing, in the background, a figure of blue sky with illustration of a green field and dawn, predominantly light blue and green. Illustration of a glass } \\
\text { containing a beige liquid. Product brand written in green font and brand logo in red with yellow fonts. Product flavor and other texts on the main panel printed } \\
\text { in blue. Packaging claims: "source of protein, iron and vitamins A, B6, B12, C, D, E and folic acid", "soy", "0\% lactose and cholesterol". }\end{array}$ \\
\hline c & $\begin{array}{l}\text { Main panel with background in leaf green color and a glass containing beige liquid with splash. Product logo written in clear font within a blue band. Product } \\
\text { name written in green. Other information from the main panel written in white font. Contains expressions "naturally lactose free and cholesterol free", "does } \\
\text { not contain milk or dairy products" and "calcium source". }\end{array}$ \\
\hline D & $\begin{array}{l}\text { Main panel containing, in the background, an illustration of a blue sky with some white clouds and a green soybean plantation, predominantly leaf green and sky } \\
\text { blue. Contains illustration of a glass containing a beige liquid with a splash. Product brand with white fonts printed inside a blue band. Other texts in the main } \\
\text { panel with white font. The claims of the package are: "soy", "no cholesterol and lactose like any product of vegetable origin" and "source of vitamins A and D". }\end{array}$ \\
\hline $\mathrm{E}$ & $\begin{array}{l}\text { Main panel in dark blue color, with some light spots and a red heart illustration. Predominant figure of a glass containing a beige liquid with splash. Brand and } \\
\text { other information from the main panel written in blue. Brand logo in blue, green and White colors. The main panel contains the expressions: "0\% cholesterol and } \\
0 \% \text { lactose" and "source of vitamin A, rich in vitamin D". }\end{array}$ \\
\hline
\end{tabular}

Annex 2. Table 2: Summary containing the main comments obtained from the focus group participants.

\begin{tabular}{|c|c|c|c|c|c|c|c|}
\hline \multirow{2}{*}{ Characteristics } & \multicolumn{7}{|c|}{ Comments from consumer groups in each of the sessions } \\
\hline & Group 1 & Group 2 & Group 3 & Group 4 & Group 5 & Group 6 & Group 7 \\
\hline Ilustration & $\begin{array}{c}\text { 'The packaging } \\
\text { has bright colors is } \\
\text { essential'. 'I like clear } \\
\text { packaging without } \\
\text { too much visual } \\
\text { pollution'. 'I always } \\
\text { check if it has other } \\
\text { flavors through the } \\
\text { phrase "try it too"'. }\end{array}$ & $\begin{array}{l}\text { 'I think clear } \\
\text { packaging is more } \\
\text { accepted'. 'I like } \\
\text { to see the splash' } \\
\text { 'I don't like to } \\
\text { see the soy bean } \\
\text { in the package' }\end{array}$ & $\begin{array}{c}\text { 'I don't like dark } \\
\text { packaging, I feel in a } \\
\text { low mood'. 'I like to } \\
\text { see the countryside } \\
\text { and the sky'. }\end{array}$ & $\begin{array}{l}\text { 'The liquid in the } \\
\text { illustration could be } \\
\text { lighter'. 'I like the } \\
\text { liquid coming out of } \\
\text { the glass in the form } \\
\text { of droplets, it seems } \\
\text { to be a fresh product' }\end{array}$ & $\begin{array}{l}\text { 'I don't remember } \\
\text { anything when I } \\
\text { Iook at this package. } \\
\text { It's very faded. Very } \\
\text { clear'.'I don't like } \\
\text { this glass floating'. }\end{array}$ & $\begin{array}{l}\text { 'I like to see this } \\
\text { family smiling. Gives } \\
\text { me the feeling of } \\
\text { happiness'. 'I prefer } \\
\text { light colors'. 'In 3th } \\
\text { package, the liquid } \\
\text { inside the cup looks } \\
\text { like a pudding' } \\
\text { 'The glass with the } \\
\text { splash is prettier' }\end{array}$ & $\begin{array}{l}\text { 'This green field on } \\
\text { the } 4 \text { th package } \\
\text { reminds me of my } \\
\text { region of origin } \\
\text { and I like it'. 'I } \\
\text { don't like very dark } \\
\text { colors, it reminds } \\
\text { us of cleaning and } \\
\text { hygiene products' }\end{array}$ \\
\hline Brand & \begin{tabular}{l} 
'Lower price is \\
very relevant'. \\
'If the product is \\
good, I look for \\
other products of \\
the same brand'. \\
'I prefer products \\
with the 'open\} $\\
{\text { close' lid' (comment }} \\
{\text { often cited). 'I buy }} \\
{\text { according to the }} \\
{\text { brand, if I trust, I buy' }}$ & $\begin{array}{c}\text { 'Price is something } \\
\text { extremely relevant'. } \\
\text { 'It would be better if } \\
\text { the expiration date } \\
\text { were printed in larger } \\
\text { print'. 'Like other } \\
\text { branded products'. } \\
\end{array}$ & $\begin{array}{c}\text { 'Because they } \\
\text { consume a lot of soy } \\
\text { drink, they buy from } \\
\text { several brands'. 'They } \\
\text { don't take the price } \\
\text { into consideration too } \\
\text { much'. 'Part of the } \\
\text { group purchases the } \\
\text { product considering } \\
\text { the fact that they } \\
\text { have purchased } \\
\text { another item of } \\
\text { the brand that } \\
\text { they' have already } \\
\text { consumed and liked }\end{array}$ & $\begin{array}{l}\text { 'Validity is always } \\
\text { the first thing to } \\
\text { look out for'. } \\
\text { 'I prefer products } \\
\text { from regional } \\
\text { cooperatives' } \\
\text { 'I buy more when } \\
\text { its on sale' }\end{array}$ & \begin{tabular}{|} 
'I do not take into \\
account where the \\
product comes from'. \\
'The product being \\
beautiful, apparently \\
and of quality, is \\
what matters'.
\end{tabular} & $\begin{array}{c}\text { 'It does not } \\
\text { necessarily have to } \\
\text { be from a famous } \\
\text { brand. What really } \\
\text { matters is the quality } \\
\text { of the product'. } \\
\text { 'I would like the } \\
\text { product to be } \\
\text { cheaper'. 'Different } \\
\text { brands usually have a } \\
\text { strong soy flavor and } \\
\text { the product is bad' }\end{array}$ & $\begin{array}{l}\text { 'If I buy something } \\
\text { from the brand } \\
\text { and I like it, I } \\
\text { buy it again'. } \\
\text { 'Brand is what } \\
\text { makes me choose } \\
\text { a product, since } \\
\text { all are always } \\
\text { expensive. If it was } \\
\text { cheaper, I'd try it, } \\
\text { but usually, those } \\
\text { with an unknown } \\
\text { brand are bad' }\end{array}$ \\
\hline $\begin{array}{l}\text { Nutritional } \\
\text { information } \\
\text { and data }\end{array}$ & $\begin{array}{c}\text { 'The information is } \\
\text { very relevant, but I } \\
\text { don't like it to be too } \\
\text { much on the front of } \\
\text { the pack'. 'Validity is } \\
\text { the first thing I notice, } \\
\text { it would be better if } \\
\text { it were more visible'. } \\
\text { 'It is important to } \\
\text { know the origin } \\
\text { of the product'. }\end{array}$ & $\begin{array}{l}\text { 'I like the phrase } \\
\text { "shake it well" but } \\
\text { you always forget } \\
\text { to shake it'. 'I like to } \\
\text { see the claims and } \\
\text { read the expression } \\
\text { "0\% lactose and } \\
\text { cholesterol"'. } \\
\text { 'It's good when } \\
\text { there's something } \\
\text { extra (calcium, } \\
\text { vitamins)'. }\end{array}$ & $\begin{array}{l}\text { The group would } \\
\text { like the letters and } \\
\text { numbers to be in } \\
\text { larger fonts. They like } \\
\text { tips on other flavors } \\
\text { of products to be } \\
\text { consumed. Labels } \\
\text { could have larger } \\
\text { fonts. 'I prefer it } \\
\text { when it has calcium, } \\
\text { vitamins and zinc'. } \\
\text { 'I do not take it if it } \\
\text { contains lactose'. }\end{array}$ & $\begin{array}{l}\text { They don't like } \\
\text { packaging with } \\
\text { English words. } \\
\text { 'Nutritional claims } \\
\text { are important in the } \\
\text { purchase decision } \\
\text { but should not be } \\
\text { exaggerated'. }\end{array}$ & \begin{tabular}{|c|} 
'Maybe they could \\
have recipes. It would \\
be interesting'. 'I like \\
it when the product \\
has calcium, iron \\
and vitamins. If it can \\
be low in calories, \\
it's also better'.
\end{tabular} & $\begin{array}{l}\text { 'The highlight of the } \\
\text { benefits that this } \\
\text { product brings to } \\
\text { health is something } \\
\text { that attracts me'. I } \\
\text { like fortified product. }\end{array}$ & $\begin{array}{l}\text { 'I prefer products } \\
\text { that contain } \\
\text { vitamins'. 'Because } \\
\text { of my age I } \\
\text { prefer products } \\
\text { with calcium } \\
\text { and without } \\
\text { cholesterol'. }\end{array}$ \\
\hline
\end{tabular}
\end{tabular}

